\title{
Effects of acetaminophen and mannitol on crush injuries in rats: An experimental study
}

\author{
Mustafa Ferudun Çelikmen, M.D., ${ }^{1}$ Sezgin Sarıkaya, M.D.,, ${ }^{1}$ Doğaç Niyazi Özüçelik, M.D., ${ }^{2}$ \\ Mehmet Şükrü Sever, M.D., ${ }^{3}$ Kurtuluş Açıksarı, M.D., ${ }^{4}$ Deniz Maktav Çelikmen, M.D., ${ }^{5}$ \\ Mustafa Yazıcıoğlu, M.D., ${ }^{6}$ Ali Kandemir, M.D., ${ }^{1}$ Halil Doğan, M.D., ${ }^{6}$ Barış Murat Ayvacı, M.D., ${ }^{7}$ \\ Derya Özaşır Abuşka, M.D., ${ }^{8}$ Sıla Sadılıoğlu, M.D. ${ }^{9}$
}

\begin{abstract}
1'Department of Emergency, Yeditepe University Faculty of Medicine, İstanbul-Turkey
${ }^{2}$ Istanbul University Health Sciences Faculty, İstanbul-Turkey

${ }^{3}$ Department of Nephrology, İstanbul University Faculty of Medicine, İstanbul-Turkey

${ }^{4}$ Department of Emergency Medicine, İstanbul Medeniyet University Faculty of Medicine, İstanbul-Turkey

${ }^{5}$ Department of Internal Medicine, Haydarpaşa Numune Training and Research Hospital, İstanbul-Turkey

${ }^{6}$ Department of Emergency, Bakırköy Dr. Kadi Konuk Training and Research Hospital, İstanbul-Turkey

${ }^{7}$ Department of Emergency, Okmeydanı Training and Research Hospital, İstanbul-Turkey

${ }^{8}$ Department of Emergency, Haseki Training and Research Hospital, İstanbul-Turkey

${ }^{9}$ Department of Emergency, İstanbul Training and Research Hospital, İstanbul-Turkey
\end{abstract}

\section{ABSTRACT}

BACKGROUND: The present objective was to evaluate effects of acetaminophen and mannitol on renal function and histopathology in crush injuries.

METHODS: Thirty-six rats weighing $370-400 \mathrm{~g}$ each were used. No surgery was performed on the first (control) group. The gastrocnemius muscle regions of each rat in the remaining 5 groups were compressed for 2 or 24 hours. In the $4^{\text {th }}$ group, $100 \mathrm{mg} /$ $\mathrm{kg}$ acetaminophen was intraperitoneally administered. In the $5^{\text {th }}$ group, I g/ $/ \mathrm{kg}$ mannitol was administered. In the $6^{\text {th }}$ group, $100 \mathrm{mg} / \mathrm{kg}$ acetaminophen and $\mathrm{I} \mathrm{g} / \mathrm{kg}$ mannitol were administered.

RESULTS: No statistically significant differences were observed among the treatment groups in terms of sodium, potassium, alanine aminotransferase (ALT), and average creatinine clearance values. Hydropic degeneration, tubular necrosis, presence of immunoperoxidase and myoglobin, tubulus epithelial cell degeneration, and presence of PAS-dyed material in tubular lumen was more prominently decreased in the acetaminophen group than the mannitol group. Improvement was observed in the group that was administered both drugs, compared to the mannitol-only group, though findings were still worse than those of the group administered acetaminophen only.

CONCLUSION: In crush injuries, acetaminophen improves histopathological renal damage better than mannitol. When used in conjunction with mannitol, the toxic effect of acetaminophen on the liver is decreased.

Keywords: Acetaminophen; crush injury; earthquake; experimental work; mannitol; renal damage.

Address for correspondence: Doğaç Niyazi Özüçelik, M.D. Demirkapı Cad., Karabal Sok., Bakırköy Ruh ve Sinir Hastalıkları Hastanesi Bahçesi İçi, 34740 Bakırköy, İstanbul, Turkey Tel: +90 212 - 4147 I 02 E-mail: dogacniyazi@gmail.com

Qucik Response Code Ulus Travma Acil Cerrahi Derg

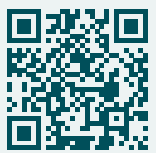
2016;22(4):305-314 doi: $10.5505 /$ tites.2015.76824

Copyright 2016 TJTES

\section{INTRODUCTION}

Crush syndrome is the second most common cause of death in immediate survivors of earthquakes. ${ }^{[1]}$ In major earthquakes, up to $20 \%$ of deaths occur shortly after extrication. [2] Causes of mortality in crush syndrome include hypovolemic shock, hyperkalemia, hypocalcemia, metabolic acidosis, acute tubular necrosis, and acute myoglobinuric renal failure. [3-5] Serum potassium, creatinine, and creatinine kinase levels are important parameters, determining crush syndrome severity. ${ }^{[6]}$ 
After the Kobe earthquake, the mortality rate of patients hospitalized early with crush syndrome was $13.4 \%$, while the same rate for traumas other than crush damage was $5.5 \% .^{[10]}$ After the Marmara earthquake, acute renal problems due to crush injury were observed in 639 of 5302 patients hospitalized with crush syndrome at 35 centers. ${ }^{[7]}$

In many crush casualties, acute kidney injuries can be prevented by appropriate early fluid resuscitation. ${ }^{[8,9]}$ Fundamental targets in crush syndrome management are early aggressive hydration, urine alkalinization, and mannitol treatment. [10-12] Administration of continuous fluids to victims as soon as possible following extrication helps prevent crush-related acute kidney injuries. Preferred fluid is isotonic saline for reasons of efficacy and availability. ${ }^{[1,11,13]}$ Sodium bicarbonate, added to half-isotonic solutions, may be effective for alkalizing urine in order to prevent tubular deposition of myoglobin and uric acid, to correct metabolic acidosis, and to reduce hyperkalemia. ${ }^{[1,12]}$ Mannitol may be useful in the expansion of extracellular volume, as well as increasing urine output, and preventing renal tubular cast deposition. ${ }^{[14]}$ However, severe side effects have been associated, including congestive heart failure in the event of overdose, as well as potential nephrotoxicity. ${ }^{[15,16]}$

New treatment protocols for preventing fatal organ damage, including acute renal failure, in cases of crush syndrome are being investigated. Results of in-vitro and in-vivo studies have shown that acetaminophen decreases the possibility of the ferryl heme transforming into ferric form, induces lipid peroxidation of hemoproteins, and promotes the formation of globin radicals. ${ }^{[1-19]}$ Cytoprotective effects of acetaminophen against organ damage in rats have been observed. ${ }^{[18]}$ In addition, acetaminophen is inexpensive, easily available, and suitable for use in all populations, including pregnant women.

The present aim was to compare effects of acetaminophen, mannitol, and acetaminophen-mannitol combination in the prevention of rhabdomyolysis, acute renal damage, and other fatal complications in rats with induced crush injuries.

\section{MATERIALS AND METHODS}

\section{Study Design and Settings}

The present experimental study was conducted at the Experimental Medicine and Research Center of the Yeditepe University Faculty of Medicine. Approval was obtained from the local ethics committee, that of the Yeditepe University for Animal Studies (issue: I5I; decision number: 02.12.2010).

\section{Closed-Piston Model}

Closed-piston model was utilized by means of 2 metal crushing devices previously described in the literature. ${ }^{[20,21]}$ The device (longitudinal axis: $15 \mathrm{~cm}$; horizontal axis: $11 \mathrm{~cm}$ ) had a maximum piston-effective pressure of 80 pounds $(\sim 36 \mathrm{~kg})$ when tightened with a screw system. The crushing procedure was performed on 2 gastrocnemius muscles simultaneously by application of pressure of 40 pounds $(\sim 18 \mathrm{~kg})$ from the 2 $\mathrm{I}-\mathrm{cm}$ circular components at the end of the screw (Fig. I).

\section{Experiment Animals}

The present study included 36 Sprague-Dawley rats weighing $370-400 \mathrm{~g}$ each. For 7 days prior to initiation of the study, the animals were kept in metal cages in an environment controlled at $22^{\circ} \mathrm{C}$, with a 12-hour light/dark cycle. In order to assess the effectiveness of the mechanical crush, a pilot study was performed on 2 rats. The remaining 36 rats were separated into groups of 6 rats each.

\section{Pilot Study}

A pilot mechanical crushing procedure was performed on 2 rats in order to ensure that it could be performed effectively, similar to the rodent model of Kirsten Speck et al. ${ }^{[22]}$ After
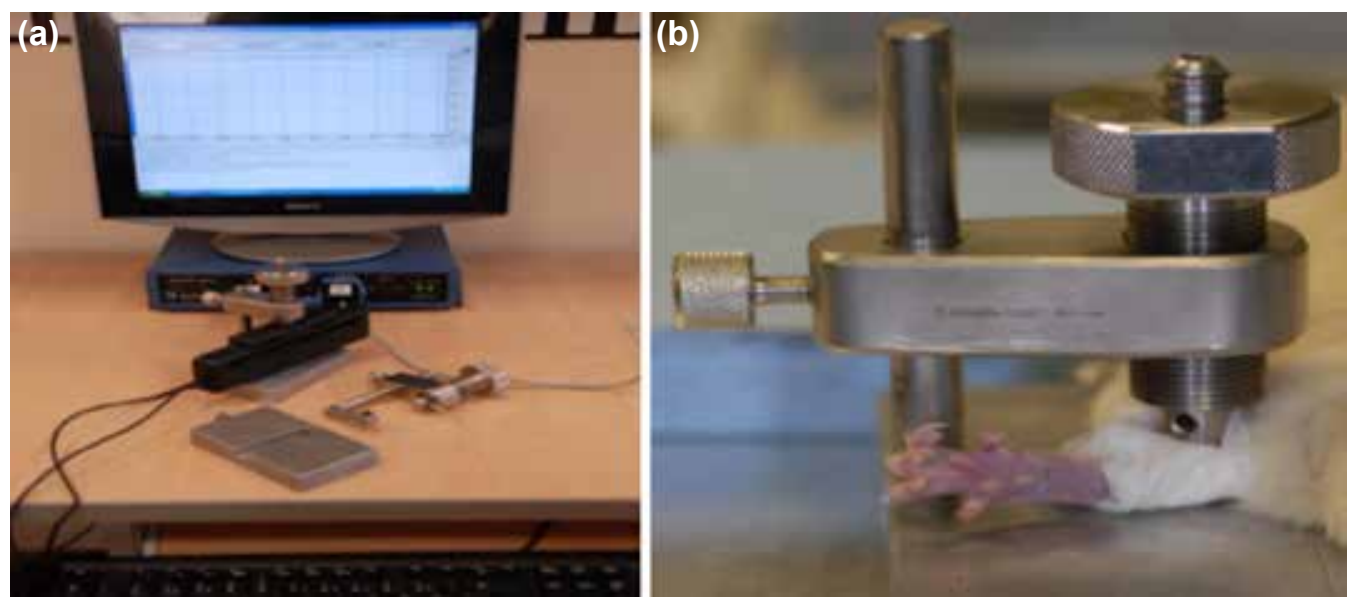

Figure 1. (a) Pressure continuity of crushing device in equivalent intervals at $40 \mathrm{lbs}(\sim 18 \mathrm{~kg})$ by Biopac MP 35 device (BIOPAC Systems, Inc., Goleta, CA, USA). (b) In order to prevent slippage of the crushing device piston, as well as skin maceration, the gastrocnemius regions were wrapped loosely with 1 fold of 5-cm plaster without harming circulation, creating a surface area. 
the rats had undergone the 2-hour procedure under anesthesia and no mobility limitations were observed, the study was modified to include compression of both of the lower-extremity gastrocnemius muscles, dissimilar to previous studies. ${ }^{[22-24]}$

\section{Anesthesia}

All rats received $40 \mathrm{mg} / \mathrm{kg}$ zolazepam hydrogen chloride (Zoletil 50 flakon; Tum İlaç San., İstanbul, Turkey) and $10 \mathrm{mg} / \mathrm{kg}$ xylazine (Rompun flakon; Bayer AG, Leverkusen, Germany) during compression and during surgery. Anesthesia was intramuscularly administered in the right leg.

\section{Crush Method}

With the exception of the control group, the rats received simultaneous and stable $40-\mathrm{lb}(\sim 18 \mathrm{~kg})$ pressure on both gastrocnemius regions for 2 hours under general anesthesia. To prevent slippage of the crushing device piston and skin maceration, the regions were wrapped loosely with I fold of $5-\mathrm{cm}$ plaster (Hypafix; BSN Medical GmbH, Hamburg, Germany) without inhibiting circulation, creating a surface area. ${ }^{[25-27]}$ Following application of compression, all rats were placed in metabolic cages, in an environment with a 12-hour light/ dark cycle, temperature of $24^{\circ} \mathrm{C}$, and free access to water. All were able to utilize the lower extremities when the effects of anesthesia diminished.

\section{Experimental Groups}

Group I: (Control group; $n=6$ ): No compression was applied.

Group 2: (2-hour compression group; $\mathrm{n}=6) .40 \mathrm{lbs}(\sim 18 \mathrm{~kg}) /$ $\mathrm{cm}^{2}$ pressure was applied for 2 hours to both gastrocnemius regions of each rat.

Group 3: (24-hour compression group; $\mathrm{n}=6) .40 \mathrm{lbs}(\sim \mid 8 \mathrm{~kg}) /$ $\mathrm{cm}^{2}$ pressure was applied for 24 hours to both gastrocnemius regions of each rat.

Group 4: (Acetaminophen group; $n=6$ ). Immediately following removal of compression, which had lasted 2 hours, 100 $\mathrm{mg} / \mathrm{kg}$ acetaminophen, titrated with distilled water in a $1: 10$ solution, was intraperitoneally administered at $4 \mathrm{~mL} / 400 \mathrm{~g}$.

Group 5: (Mannitol group; $n=6$ ). Immediately following removal of compression, which had lasted 2 hours, $1 \mathrm{~g} / \mathrm{kg}$ mannitol $20 \%$ solution was intraperitoneally administered at 2 $\mathrm{mL} / 400 \mathrm{~g}$.

Group 6: (Acetaminophen + mannitol group; $n=6$ ). Immediately following removal of compression, which had lasted 2 hours, doses of acetaminophen and mannitol identical to those of Groups 5 and 6, were consecutively and intraperitoneally administered.

\section{Urine Examination of Samples}

The urine samples of (untreated) Group 2 rats were obtained following the 2-hour period of compression. Urine samples of the other groups were obtained at 24 hours and stored at $4^{\circ} \mathrm{C}$.

\section{Biochemical Examination of the Samples}

Under sterile conditions, cardiac puncture was performed for biochemical analysis, and 4-5 mL blood samples were obtained. Samples were centrifuged for 10 minutes and 3000 spins at $4^{\circ} \mathrm{C}$. They were stored at $-20^{\circ} \mathrm{C}$ in the Yeditepe University Medical School Biochemistry laboratory. Sodium, potassium, alanine aminotransferase (ALT), urine, and serum creatinine measurements were performed with use of relevant kits in a Cobas Integra 400 plus autoanalyzer (Roche Diagnostics International AG, Rotkreuz, Switzerland). As serum myoglobin is cleaned from plasma in 6 hours, and the majority of samples were gathered after 24 hours, myoglobin was not included in biochemical sample evaluation. Myoglobin evaluation was scored as histopathological. ${ }^{[1]}$

\section{Collection of Histological Samples}

Samples were obtained in an identical manner, performed on an operation table under general anesthesia. Twenty-four hours after initial surgery, the surgical area was cleansed with $10 \%$ povidone-iodine, and the abdomen was cut with a $2-\mathrm{cm}$ midline incision starting at $\mathrm{I} \mathrm{cm}$ below the xiphoid process. Upon accessing the retroperitoneum, bilateral nephrectomy was performed for pathological study. Left and right kidneys were halved with a lancet through the long axis, and cubic sections $1 \times 1 \times 0.5 \mathrm{~cm}$ in depth were obtained from both lower extremity gastrocnemius muscles. Two muscle cuts from each rat were prepared in the coronal and axial plan. The sections were placed in 10\% formaldehyde for histopathological evaluation. Each sampling surgery was completed in nearly 10 minutes.

\section{Histopathological Examination}

Kidney and muscle samples used for histopathological study were fixed in $10 \%$ formaldehyde solution for 24 hours and tracked routinely by sampling at $0.5-\mathrm{cm}$ thickness in the Yeditepe University Medical School Pathology Department. Tissue samples were embedded in paraffin blocks, and cuts of $5-\mu \mathrm{m}$ thicknesses were prepared. Samples were dyed with hematoxylin-eosin and examined under light microscope. In each preparation, kidney damage was assessed in 10 randomized areas. Hydropic degeneration in the proximal tubules, and inflammation and necrosis in the tubule were scored semiquantitatively, with 0 points signifying no change, I point signifying change of less than $25 \%$ (mild), 2 points signifying change of $25-50 \%$ (mid-range), 3 points signifying change of $50-75 \%$ (extreme), and 4 points signifying change of $75 \%$ (very extreme).

\section{Immunohistochemical Examination}

Following histopathological examination, myoglobin antibody 
(species reactivity: human, mouse, rat; - $100 \mathrm{Amb}$ ) dyeing was performed immunohistochemically on the cuts using the avidin-biotin-peroxidase method. The 5- $\mathrm{mm}$ cuts were deparaffinized and rehydrated. In order to prevent endogenous peroxidase activity, they were kept in 3\% peroxide for 5 minutes before being cleansed in distilled water. The cuts were then stored in citrate buffer solution at $\mathrm{pH} 6$ (650 microwave) for 5 minutes and kept in Tris buffer solution for 5 minutes. The primary antibody was kept in a humid environment at $28^{\circ} \mathrm{C}$ for 30 minutes. Biotin-marked secondary antibody was administered for 15 minutes, was placed in streptavidin peroxidase conjugate for 10 minutes, then in 3-amino-9-ethylcarbazole (AEC) chromogen for 15 minutes. Every level was washed. Mayer's hematoxylin was used as background counter dye and closed with a special closing material before being prepared for microscopic examination.

Semiquantitative scoring was performed according to myoglobin dying properties in arteries, in the proximal tubule, distal tubule, in glomeruli and collecting channels, as well as in 10 areas at $40-\mathrm{mm}$ objective. Points were assigned based on the following criteria: 0 point: no change; I point: change of less than $25 \%$ (mild); 2 points: $25-60 \%$ change (mid-range); 3 points: change of $60 \%$ and greater (extreme).

\section{Statistical Methods}

Statistical analyses were performed using NCSS statistical software (NCSS LLC, East Kaysville, UT, USA; 2007). Descriptive statistical methods (average, SD, median, interquartile range) were applied, as were tests, including KruskalWallis, to determine intergroup comparison. Dunn's multiple comparison test was used to compare subgroups; chi-square test was used to compare qualitative data, and $p<0.05$ was considered significant.

\section{RESULTS}

Laboratory results are shown in Table I.

Average creatinine value closest to that of the control group was observed in the 2-hour compression group. Lowest mean creatinine value among the treatment groups was observed in the acetaminophen group $(0.83 \pm 0.7 \mathrm{mg} / \mathrm{dL})$, while the highest creatinine level was observed in the mannitol group ( $1.2 \mathrm{I} \pm \mathrm{l} .75 \mathrm{mg} / \mathrm{dL} ; \mathrm{p}=0.177)$.

Mean creatinine clearance value closest to that of the control group was observed in the acetaminophen group (I.35 \pm 0.48 $\mathrm{mL} / \mathrm{min}$ ), which also had the highest mean creatinine clearance value. Among the treatment groups, the lowest mean creatinine clearance value was observed in group that had been administered both acetaminophen and mannitol $(0.63 \pm 0.4 \mathrm{~mL} / \mathrm{min} ; \mathrm{p}=0.00 \mathrm{I})$.

While creatinine clearance was found to be significantly different between the control and treatment groups $(p<0.05)$, no statistically significant difference was observed between the groups that had been administered either acetaminophen or mannitol, a finding determined using Dunn's multiple comparison test $(p>0.05)$.

ALT value closest to that of the control group was observed in

Table I. Laboratory results of the study groups

\begin{tabular}{|c|c|c|c|c|c|}
\hline \multirow[t]{2}{*}{ Study groups } & \multicolumn{5}{|c|}{ Laboratory results (Means \pm SD) } \\
\hline & Creatinine (mg/dl) & Cr. Cl (ml/min) & ALT (IU/L) & $\mathrm{Na}(\mathrm{mmol} / \mathrm{L})$ & $\mathrm{K}(\mathrm{mmol} / \mathrm{L})$ \\
\hline Control group & $0.48 \pm 0.12$ & $1.86 \pm 0.31$ & $57.97 \pm 17.2$ & $135.15 \pm 20.12$ & $6.5 \pm 1.26$ \\
\hline \multicolumn{6}{|l|}{ Crush plus } \\
\hline 2. hours group & $0.53 \pm 0.11$ & $0.14 \pm 0.12$ & $106.63 \pm 26.39$ & $157.78 \pm 40.16$ & $7.77 \pm 2.02$ \\
\hline \multicolumn{6}{|l|}{ Crush plus } \\
\hline 24. hours group & $0.85 \pm 0.33$ & $0.54 \pm 0.22$ & $225.9 \pm 108.57$ & $134.79 \pm \mid 4.87$ & $8.15 \pm 2.41$ \\
\hline \multicolumn{6}{|l|}{ Crush plus } \\
\hline Acetaminophen group & $0.83 \pm 0.7$ & $1.35 \pm 0.48$ & $276.22 \pm 152.25$ & $133.02 \pm 8.37$ & $7.47 \pm 0.85$ \\
\hline \multicolumn{6}{|l|}{ Crush plus } \\
\hline Mannitol group & $1.5 \pm 1.34$ & $1.01 \pm 0.16$ & $195.45 \pm 17.06$ & $138.4 \pm 3.69$ & $9.44 \pm 1.36$ \\
\hline \multicolumn{6}{|l|}{ Crush plus } \\
\hline \multicolumn{6}{|l|}{ Acetaminophen plus } \\
\hline Mannitol group & $1.21 \pm 1.75$ & $0.63 \pm 0.4$ & $259.2 \pm 128.04$ & $135.6 \pm 6.73$ & $7.36 \pm 1.08$ \\
\hline Kruskal Wallis & 7.64 & 29.31 & 21.46 & 7.59 & 11.27 \\
\hline$P$ & 0.177 & 0.0001 & 0.001 & 0.180 & 0.048 \\
\hline
\end{tabular}

SD: Standard deviation; Cr. Cl: Creatinine clearance; ALT: Alanine aminotransferase; Na: Sodium; K: Potassium. 
the 2-hour compression group (106.63 $\pm 26.39 \mathrm{IU} / \mathrm{L})$. Among the treatment groups, the lowest mean ALT value was observed in the mannitol group (195.45 $17.06 \mathrm{IU} / \mathrm{L})$, while the highest mean ALT value was observed in the acetaminophen group (276.22 \pm I $52.25 \mathrm{IU} / \mathrm{L} ; \mathrm{p}=0.00 \mathrm{I})$.

While ALT difference between the control and treatment groups was statistically significant $(p<0.05)$, no significant difference was observed between the 24-hour compression group and the acetaminophen or mannitol groups ( $p>0.05)$, a finding obtained using Dunn's multiple comparison test.

Mean sodium value closest to that of the control group was observed in the 24-hour compression group (I34.79 14.87 $\mathrm{mmol} / \mathrm{L})$. Among the treatment groups, the lowest mean sodium value was found in the acetaminophen group ( $133.02 \pm 8.37 \mathrm{mmol} / \mathrm{L})$, while the highest was observed in the mannitol group ( $138.4 \pm 3.69 \mathrm{mmol} / \mathrm{L} ; \mathrm{P}=0.180)$.

Mean potassium value closest to that of the control group was found in the group that had been administered both acetaminophen and mannitol $(7.36 \pm 1.08 \mathrm{mmol} / \mathrm{L})$. This group also had the lowest mean potassium value. Among the treatment groups, the highest mean potassium value was observed in the mannitol group $(9.44 \pm 1.36 \mathrm{mmol} / \mathrm{L} ; \mathrm{p}=0.048)$. While differences in potassium between the control and treatment groups were statistically significant $(p<0.05)$, no statistically significant difference was observed between the group administered mannitol and the other groups ( $p>0.05)$, a finding determined using Dunn's multiple comparison test.

Scores indicating hydropic degeneration, tubular necrosis, and inflammation are shown in Table 2. Immunoperoxidase and myoglobin, tubulus epithelial cell degeneration, and PAS plus protein scores are shown in Table 3.

While extreme or very extreme hydropic degeneration was observed in $100 \%$ of rats in the 2- and 24-hour untreated groups, moderate, extreme or very extreme hydropic degeneration was observed in $50 \%$ of the acetaminophen group, $100 \%$ of the mannitol group, and 100\% of the group receiving both acetaminophen and mannitol treatment. No hydropic degeneration was observed in $16.66 \%$ of the acetaminophen group. Difference in intergroup hydropic degeneration was statistically significant $(p=0.000 \mathrm{I})$.

While moderate, extreme, or very extreme tubular necrosis was observed in $100 \%$ of rats in the 2- and 24-hour untreated groups, moderate tubular necrosis was observed in $16.6 \%$ of the group receiving acetaminophen treatment, $66.6 \%$ of the group receiving mannitol treatment, and $66.6 \%$ of the group receiving both acetaminophen and mannitol treatment. Inter-

Table 2. Scores of hydropic degeneration, tubular necrosis, and inflammation in groups (+: mild; ++: moderate; +++: severe; ++++: very severe)

\begin{tabular}{|c|c|c|c|c|c|c|c|}
\hline & \multirow[t]{2}{*}{ Scores } & \multirow{2}{*}{$\frac{\text { Group }}{\text { Control }}$} & \multicolumn{5}{|c|}{ Crush groups } \\
\hline & & & 2 hours & 24 hours & Acetaminophen & Mannitol & Acetaminophen plus mannitol \\
\hline \multirow[t]{6}{*}{ HD } & No & 6 & 0 & 0 & I & 0 & 0 \\
\hline & $(+)$ & 0 & 0 & 0 & 2 & 0 & 0 \\
\hline & $(++)$ & 0 & 0 & 0 & 2 & 3 & 4 \\
\hline & $(+++)$ & 0 & 5 & 3 & 1 & 3 & 2 \\
\hline & $(++++)$ & 0 & 1 & 3 & 0 & 0 & 0 \\
\hline & \multicolumn{7}{|c|}{$\chi^{2}: 62.61 \mathrm{p}=0.0001$} \\
\hline \multirow[t]{6}{*}{ TN } & No & 6 & 0 & 0 & 3 & 0 & 0 \\
\hline & $(+)$ & 0 & 0 & 0 & 2 & 2 & 2 \\
\hline & $(++)$ & 0 & 2 & 0 & 1 & 4 & 4 \\
\hline & $(+++)$ & 0 & 4 & 3 & 0 & 0 & 0 \\
\hline & $(++++)$ & 0 & 0 & 3 & 0 & 0 & 0 \\
\hline & \multicolumn{7}{|c|}{$\chi^{2}: 65.61 \mathrm{p}=0.0001$} \\
\hline \multirow[t]{6}{*}{ Inflammation } & No & 6 & 0 & 0 & 3 & 0 & 0 \\
\hline & $(+)$ & 0 & 0 & 0 & 3 & I & 5 \\
\hline & $(++)$ & 0 & 5 & 2 & 0 & 5 & 1 \\
\hline & $(+++)$ & 0 & 1 & 4 & 0 & 0 & 0 \\
\hline & $(++++)$ & 0 & 0 & 0 & 0 & 0 & 0 \\
\hline & \multicolumn{7}{|c|}{$\chi^{2}: 63.12 p=0.000$} \\
\hline
\end{tabular}


group tubular necrosis difference was statistically significant $(p=0.0001)$.

Moderate, extreme, or very extreme inflammation was observed in $100 \%$ of the 2- and 24-hour untreated groups. However, inflammation was observed in $0 \%$ of the group receiving acetaminophen treatment, $83.3 \%$ of the group receiving mannitol treatment, and $16.6 \%$ of the group receiving both acetaminophen and mannitol. Intergroup inflammation was statistically significant $(p=0.000)$.

While moderate and extreme immunoperoxidase and myoglobin was observed in $100 \%$ of the 2- and 24-hour untreated groups, moderate immunoperoxidase and myoglobin was observed in $16.6 \%$ of the acetaminophen group, $33.3 \%$ of the mannitol group, and $16.6 \%$ of the group receiving both acetaminophen and mannitol. Intergroup difference in immunoperoxidase and myoglobin was statistically significant $(p=0.000 \mathrm{I})$.

Moderate and extreme tubulus epithelial cell degeneration was observed in $83 \%$ of the 2 -hour untreated group, and in $100 \%$ of the 24 -hour untreated groups. Tubulus epithelial cell degeneration was observed in $16.6 \%$ of the acetaminophen group, $100 \%$ of the mannitol group, and $50 \%$ of the group receiving both acetaminophen and mannitol treatment. Intergroup difference in tubulus epithelial cell degeneration was statistically significant $(p=0.000 \mathrm{I})$.

Moderate and extreme PAS plus protein was observed in
$83 \%$ of the 2 -hour untreated group and in $100 \%$ of the $24-$ hour untreated group. PAS plus protein was observed in no rats receiving only acetaminophen treatment, $66.6 \%$ of those receiving mannitol treatment, and $50 \%$ of those receiving both. Intergroup difference in PAS plus protein was statistically significant $(p=0.000 \mathrm{I})$.

Statistically significant differences were found between the control and treatment groups regarding hydropic degeneration, tubular necrosis, inflammation, immunoperoxidase and myoglobin, tubulus epithelial cell degeneration, and PAS plus protein, when Dunn's multiple comparison test was applied $(p<0.05)$. However, no statistically significant difference in these measurements was observed between either the 2- and 24-hour groups or the acetaminophen and mannitol groups $(p>0.05)$.

Differences in tubular necrosis and tubulus epithelial cell degeneration between the control and acetaminophen groups were not statistically significant $(p>0.05)$. Neither was significant difference found between the 2-hour and mannitol groups, or the acetaminophen group and the group that had been administered both drugs $(p>0.05)$.

Regarding the untreated groups, very extreme findings of hydropic degeneration in $16.6 \%$, of immunoperoxidase and myoglobin in $66.6 \%$, of tubulus epithelial cell degeneration in $16.6 \%$, and PAS plus protein in $16.6 \%$ were observed in the 2-hour group. In the 24-hour group, extreme hydropic de-

Table 3. Scores of immunoperoxidase and myoglobin, tubulus epithelial cell degeneration, and PAS plus protein (+: mild; ++: moderate; +++: severe score)

\begin{tabular}{|c|c|c|c|c|c|c|c|}
\hline & \multirow[t]{2}{*}{ Scores } & \multirow{2}{*}{$\frac{\text { Group }}{\text { Control }}$} & \multicolumn{5}{|c|}{ Crush groups } \\
\hline & & & 2 hours & 24 hours & Acetaminophen & Mannitol & Acetaminophen plus mannitol \\
\hline \multirow[t]{5}{*}{ IM } & No & 6 & 0 & 0 & I & 0 & 0 \\
\hline & $(+)$ & 0 & 0 & 0 & 2 & 4 & 5 \\
\hline & $(++)$ & 0 & 2 & 0 & I & 2 & 1 \\
\hline & $(+++)$ & 0 & 4 & 6 & 0 & 0 & 0 \\
\hline & \multicolumn{7}{|c|}{$\chi^{2}: 59.74 p=0.0001$} \\
\hline \multirow[t]{5}{*}{ TECD } & No & 6 & 0 & 0 & I & 0 & 0 \\
\hline & $(+)$ & 0 & I & 0 & 4 & 0 & 3 \\
\hline & $(++)$ & 0 & 4 & $\mathrm{I}$ & I & 0 & 3 \\
\hline & $(+++)$ & 0 & I & 5 & 0 & 6 & 0 \\
\hline & \multicolumn{7}{|c|}{$\chi^{2}: 65.61 \mathrm{p}=0.0001$} \\
\hline \multirow[t]{5}{*}{ PASP } & No & 6 & 0 & 0 & I & 0 & 0 \\
\hline & $(+)$ & 0 & I & 0 & 5 & 0 & 4 \\
\hline & $(++)$ & 0 & 4 & 1 & 0 & 2 & 2 \\
\hline & $(+++)$ & 0 & I & 5 & 0 & 4 & 0 \\
\hline & \multicolumn{7}{|c|}{$\chi^{2}: 62.78 p=0.0001$} \\
\hline
\end{tabular}

IM: Immunoperoxidase and myoglobin; TECD: Tubulus epithelial cell degeneration; PASP: PAS plus protein. 
generation in was observed in $50 \%$, tubular necrosis in $50 \%$, inflammation in $66.6 \%$, immunoperoxidase and myoglobin in $100 \%$, tubulus epithelial cell degeneration in $83.35 \%$, and PAS plus protein was observed in $83.3 \%$.

Regarding the treatment groups, hydropic degeneration was not observed in $16.6 \%$ of the acetaminophen group, tubular necrosis was not observed in $50 \%$, inflammation was not observed in $50 \%$, immunoperoxidase and myoglobin were not observed in $6.6 \%$, tubulus epithelial cell degeneration was not observed in $16.6 \%$, and PAS plus protein in was not observed in $16.6 \%$. However, these histopathological findings were observed in the mannitol group, in different degrees and rates.

In the acetaminophen group, no instances of very extreme hydropic degeneration, tubular necrosis, inflammation, im- munoperoxidase and myoglobin, tubulus epithelial cell degeneration, or PAS plus protein were observed. In the mannitol group, very extreme tubulus epithelial cell degeneration was observed in $100 \%$ and PAS plus protein in $66.6 \%$. Very extreme histopathological findings were not found in any rats that received both acetaminophen and mannitol.

Histological changes are shown in groups of 24 hours in Figure 2. Observed in untreated compressed groups were diffuse traumatic damage in muscle bundles, inflammatory infiltration, congestion and edema, intense immunoperoxidase and myoglobin in the lumen and glomerulus structure, and PAS and myoglobin in the lumen and glomerulus structure. In damaged muscle tissue histology of the acetaminophen group, sporadic PNL infiltration, myoglobin and immune dyeing in the renal glomerulus and lumen, and normal appearance
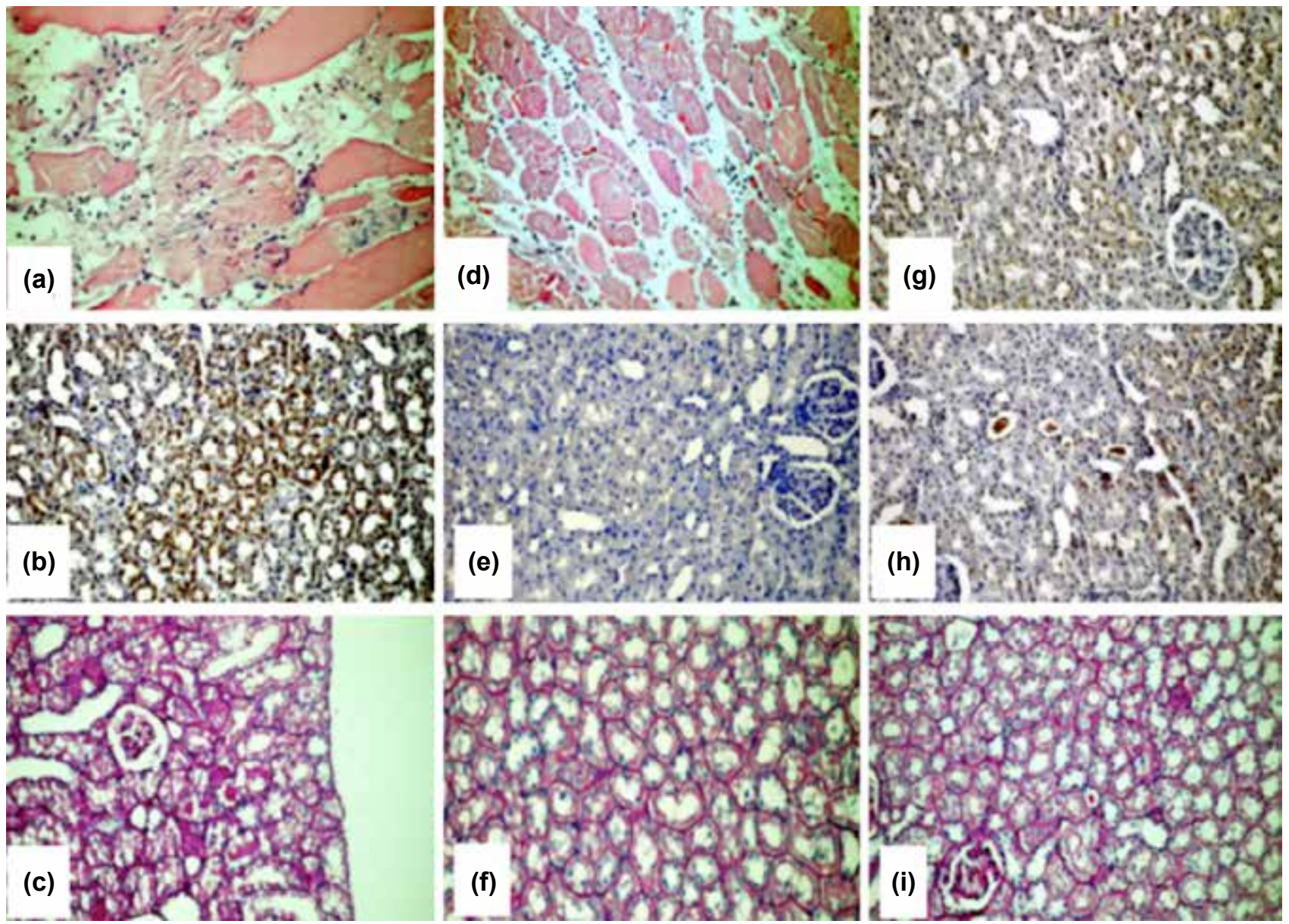

Figure 2. Histologic structure visualized in groups at 24 hours. (a) Crush without treatment, typical traumatic damage in muscle bundles, clear inflammatory infiltration, congestion, and oedema (hematoxylin-eosin, 200x). (b) Crush without treatment, intense immunoperoxidase and myoglobin in the lumen and glomerulus structure (immunoperoxidase, 200x). (c) Crush without treatment, PAS and myoglobin in the lumen and glomerulus structure (PAS, 200x). (d) Crush with acetaminophen treatment, damaged muscle tissue histology, sporadic PNL infiltration that followed (hematoxylin-eosin, 200x). (e) Crush with acetaminophen treatment, myoglobin and immune dye in the renal glomerulus and lumen are not followed (immunoperoxidase, 200x). (f) Crush with acetaminophen treatment, normal appearance of renal tubulus lumen and glomerulus structure histology (PAS, 200x). (g) Crush with acetaminophen plus mannitol treatment, sporadic tubular immunoperoxidase and myoglobin presence (immunoperoxidase, 200x). (h) Crush with mannitol treatment, sporadic tubular immunoperoxidase and myoglobin presence is followed (immunoperoxidase, 200x). (i) Crush with mannitol treatment, PAS plus myoglobin in lumen and glomerulus structure (PAS, 200X). 
of renal tubulus lumen and glomerulus structure histology were observed. In the group that had been administered acetaminophen plus mannitol treatment, sporadic tubular immunperoxidase and myoglobin were observed. In the group that was administered only mannitol treatment, sporadic tubular immunperoxidase and myoglobin were observed, as were PAS and myogobin in the lumen and glomerulus structure.

\section{DISCUSSION}

New treatment protocols are needed in order to increase rates of survival during rescues from rubble in the aftermath of earthquakes, as well as survival from other types of crush that cause wide-scale death and injury. ${ }^{[1-16,25-28]}$

In a rat model-based study, radical derivatives of rhabdomyolysis emerging as a result of redox reactions between ferric and ferryl myoglobin was shown to cause serious oxidative damage to kidneys. ${ }^{[29]}$

Several clinical and animal studies have been conducted using a number of active substances that behaved as metal-ion inactivators with the intention of aiding in the recovery of oxidative damage, scavenging free radicals, stimulating physiological enzymatic antioxidant systems, and protecting mitochondrial functions. ${ }^{[17,30-33]}$

It was presently understood that a closed, piston-activated compression model most accurately mimicked factors causing crush trauma in earthquakes. ${ }^{[20-22]}$

In animal experiments with ischemia-reperfusion models, it was shown that disruption of circulation in the extremities increased muscle damage. After removal of pressure on the extremity, myoglobin-containing oxidative ferrous derivatives that may cause cell injury, hemoglobin, lactic acid, potassium, and creatinine are released during the reperfusion. Following crush injury, change in electrolytes occurs both inside and outside the cell, and sodium-potassium-ATPase activity in the cell membrane deteriorates. ${ }^{[34-36]}$

No statistically significant decrease in sodium level was observed in the present study. However, in accordance with the findings of others, an increase in potassium was observed in all groups at the $24^{\text {th }}$ hour. ${ }^{[16,37]}$ In addition, it has been shown that mannitol and acetaminophen should be administered together to prevent hyperpotassemia in crush treatment.

Various treatments have been utilized in an attempt to decrease the extent of kidney damage following crush injury. [27,28,30,31] The lowest mean creatinine value among treatment groups, as well as the highest mean rate of creatinine clearance, were found in the acetaminophen group, while the highest creatinine level was found in the mannitol group. These results are thought to be linked to the protective effect of acetaminophen on kidney function. Tolouian R. et al. report- ed similar prophylactic benefits in studies using oral alkaline solutions. ${ }^{[27]}$

Compared to the acetaminophen group, creatinine was increased and creatinine clearance was decreased in the mannitol group. When mannitol was administered in conjunction with acetaminophen, creatinine decreased, though creatinine clearance was not increased.

Although creatinine kinase levels were high in the compressed groups, serum creatinine kinase level has low specificity in rhabdomyolysis. ${ }^{[38]}$ The most important substance secreted from muscles during rhabdomyolysis is myoglobin; levels rise and fall much faster than creatinine kinase levels (in I-6 hours). In addition, myoglobinuria is not always visible, or may be resolved early. ${ }^{[39]}$ Therefore, myoglobin and creatinine kinase levels were not evaluated in the present study.

It has been observed that enzymes in the liver are also very high in days following crush trauma, as are other biomarkers. $^{[40]}$

It was presently believed that use of acetaminophen and mannitol potentially decreased liver damage, as ALT values began to increase following compression, and the highest values were observed in the acetaminophen group, lowering when mannitol was added to treatment.

It was presently observed that ALT levels were higher in the acetaminophen group, compared to the mannitol group, an effect that decreased when mannitol was added to acetaminophen treatment. However, administration of $\mathrm{N}$-acetylcysteine, an easily found, cheap antidote, in addition to mannitol, creates an advantage in terms of therapeutic application safety.

In an in-vitro study, Boutaud $O$. et al. ${ }^{[8]}$ showed that acetaminophen decreased ferryl heme transformation into ferric form, inducing lipid peroxidation of hemoproteins, and promoting the formation of globin radicals, results also demonstrated in in-vitro and in-vivo studies conducted by Nath KA et al. ${ }^{[19]}$ In a separate study by Boutaud $O$. et al., chemical crush was induced in rats with glycerol. It was demonstrated that acetaminophen was very useful due to its antioxidant feature, cytoprotective effects, and protection against organ damage, and is also cheap, accessible, and suitable for use in all populations, including pregnant women. ${ }^{[17]}$

Few studies (either clinical or animal) have raised questions regarding the use of mannitol to treat crush injury, including vasodilatory or cytoprotective effects. ${ }^{[16,18]}$

It was also observed that the extremity of hydropic degeneration, tubular necrosis, inflammation, immunoperoxidase and myoglobin, tubulus epithelial cell degeneration, and PAS plus protein findings were elevated in the $2^{\text {nd }}$ hour, compared to 
the control group, as well as in the $24^{\text {th }}$ hour, compared to the 2-hour and control groups. It was also observed that these levels were lower in the acetaminophen group, compared to the mannitol group. When acetaminophen and mannitol were administered together, findings were better than those of the mannitol group, but worse than those of the acetaminophen group.

As a result of immunohistochemical and histopathological evaluation, it was determined that acetaminophen treatment decreased PAS plus dyed protein material presence in kidney tissue, myoglobin, and glomerulus capillary lumen. Compared to other treatments studied, acetaminophen had demonstrated preventative effects on hydropic degeneration, inflammation, tubular necrosis, and tubulus epithelial cell degeneration.

\section{Conclusion}

Results of the present experimental study demonstrate that acetaminophen is more effective than mannitol in the treatment of crush injury. Acetaminophen ameliorates histopathological renal damage and protects renal functions. When acetaminophen and mannitol are used in conjunction, the positive effects of acetaminophen are decreased, the protective effects of mannitol against renal damage and function are increased, and the toxic effect of acetaminophen on the liver is decreased, compared to treatment of acetaminophen alone. Furthermore, hyperpotassemia that occurs when mannitol is administered in isolation decreases when either acetaminophen or acetaminophen + mannitol are administered. These findings warrant further studies, prior to clinical implementation.

\section{Acknowledgement}

We would like to thank to Prof. Ahmet KAZEZ of the Firat University Medical School Pediatric Surgery Department for allowing the use of the tissue compression device.

Conflict of interest: None declared.

\section{REFERENCES}

1. Sever MS, Vanholder R; RDRTF of ISN Work Group on Recommendations for the Management of Crush Victims in Mass Disasters. Recommendation for the management of crush victims in mass disasters. Nephrol Dial Transplant 2012;27 Suppl 1:1-67. Crossref

2. Ashkenazi I, Isakovich B, Kluger Y, Alfici R, Kessel B, Better OS. Prehospital management of earthquake casualties buried under rubble. Prehosp Disaster Med 2005;20:122-33. Crossref

3. Reis ND, Better OS. Mechanical muscle-crush injury and acute musclecrush compartment syndrome: with special reference to earthquake casualties. J Bone Joint Surg Br 2005;87:450-3. Crossref

4. Visweswaran P, Guntupalli J. Rhabdomyolysis. Crit Care Clin 1999;15:415-28. Crossref

5. Smith J, Greaves I. Crush injury and crush syndrome: a review. J Trauma 2003;54(5 Suppl):226-30.

6. Rosedale KJ, Wood D. Traumatic rhabdomyolysis (crush syndrome) in the rural setting. S Afr Med J 2011;102:37-9.

7. Sever MS, Erek E, Vanholder R, Akoğlu E, Yavuz M, Ergin H, et al. The Marmara earthquake: epidemiological analysis of the victims with nephrological problems. Kidney Int 2001;60:1114-23. Crossref

8. Ron D, Taitelman U, Michaelson M, Bar-Joseph G, Bursztein S, Better OS. Prevention of acute renal failure in traumatic rhabdomyolysis. Arch Intern Med 1984;144:277-80. Crossref

9. Better OS. The crush syndrome revisited (1940-1990). Nephron 1990;55:97-103. Crossref

10. Sever MS, Vanholder R, Lameire N. Management of crush-related injuries after disasters. N Engl J Med 2006;354:1052-63. Crossref

11. Better OS, Stein JH. Early management of shock and prophylaxis of acute renal failure in traumatic rhabdomyolysis. N Engl J Med 1990;322:8259. Crossref

12. Evans KJ, Greenberg A. Hyperkalemia: a review. J Intensive Care Med 2005;20:272-90. Crossref

13. Better OS. Rescue and salvage of casualties suffering from the crush syndrome after mass disasters. Mil Med 1999;164:366-9.

14. Eneas JF, Schoenfeld PY, Humphreys MH. The effect of infusion of mannitol-sodium bicarbonate on the clinical course of myoglobinuria. Arch Intern Med 1979;139:801-5. Crossref

15. Gadallah MF, Lynn M, Work J. Case report: mannitol nephrotoxicity syndrome: role of hemodialysis and postulate of mechanisms. Am J Med Sci 1995;309:219-22. Crossref

16. Brown CV, Rhee P, Chan L, Evans K, Demetriades D, Velmahos GC. Preventing renal failure in patients with rhabdomyolysis: do bicarbonate and mannitol make a difference? J Trauma 2004;56:1191-6. Crossref

17. Boutaud O, Moore KP, Reeder BJ, Harry D, Howie AJ, Wang S, et al. Acetaminophen inhibits hemoprotein-catalyzed lipid peroxidation and attenuates rhabdomyolysis-induced renal failure. Proc Natl Acad Sci U S A 2010;107:2699-704. Crossref

18. Boutaud O, Aronoff DM, Richardson JH, Marnett LJ, Oates JA. Determinants of the cellular specificity of acetaminophen as an inhibitor of prostaglandin H(2) synthases. Proc Natl Acad Sci U S A 2002;99:71305. Crossref

19. Nath KA, Balla J, Croatt AJ, Vercellotti GM. Heme protein-mediated renal injury: a protective role for 21-aminosteroids in vitro and in vivo. Kidney Int 1995;47:592-602. Crossref

20. Özel ŞK, Köseoğulları AA, Kazez A, Akpolat N, İlhan N. Ezilme yaralanması oluşturulan sıçanlardaki böbrek hasarına melatoninin etkisi. Çocuk Cerrahisi Dergisi 2006;20:105-10.

21. Özel ŞK, Kazez A. Karın, genitoüriner ve toraks travma modelleri. In: Çakmak AM, Karagüzel G, Soyer T, Günaydın S, Karahan S, editör. Çocuk Cerrahisinde Deneysel Araştırmalar. Ankara: Özkan Matbaacılık; 2009. s. 170-5.

22. Speck K, Schneider BS, Deashinta N. A rodent model to advance the field treatment of crush muscle injury during earthquakes and other natural disasters. Biol Res Nurs 2013;15:17-25. Crossref

23. Szewczyk D, Ovadia P, Abdullah F, Rabinovici R. Pressure-induced rhabdomyolysis and acute renal failure. J Trauma 1998;44:384-8. Crossref

24. Matsen FA 3rd, Mayo KA, Sheridan GW, Krugmire RB Jr. Monitoring of intramuscular pressure. Surgery 1976;79:702-9.

25. de Bruycker M, Greco D, Annino I, Stazi MA, de Ruggiero N, Triassi M, et al. The 1980 earthquake in southern Italy: rescue of trapped victims and mortality. Bull World Health Organ 1983;61:1021-5.

26. Cho YS, Lim H, Kim SH. Comparison of lactated Ringer's solution and $0.9 \%$ saline in the treatment of rhabdomyolysis induced by doxylamine intoxication. Emerg Med J 2007;24:276-80. Crossref

27. Tolouian R, Wild D, Lashkari MH, Najafi I. Oral alkalinizing solution as a potential prophylaxis against myoglobinuric acute renal failure: preliminary data from healthy volunteers. Nephrol Dial Transplant 2005;20:1228-31. Crossref 
28. Ho KM, Sheridan DJ. Meta-analysis of frusemide to prevent or treat acute renal failure. BMJ 2006;333:420. Crossref

29. Paller MS. Hemoglobin- and myoglobin-induced acute renal failure in rats: role of iron in nephrotoxicity. Am J Physiol 1988;255(3 Pt 2):53944.

30. Zager RA. Combined mannitol and deferoxamine therapy for myohemoglobinuric renal injury and oxidant tubular stress. Mechanistic and therapeutic implications. J Clin Invest 1992;90:711-9. Crossref

31. Inal M, Altinişik M, Bilgin MD. The effect of quercetin on renal ischemia and reperfusion injury in the rat. Cell Biochem Funct 2002;20:291-6.

32. Heyman SN, Brezis M, Greenfeld Z, Rosen S. Protective role of furosemide and saline in radiocontrast-induced acute renal failure in the rat. Am J Kidney Dis 1989;14:377-85. Crossref

33. Bor MV, Durmus O, Cayçi B, Türközkan N. An alternative parameter for monitoring the therapeutic benefits of allopurinol simultaneously in renal ischaemia-reperfusion injury: MDA/ATP Ratio. Cell Biochem Funct 2000;18:229-34. Crossref

34. Vanholder R, Sever MS, Erek E, Lameire N. Rhabdomyolysis. J Am Soc
Nephrol 2000;11:1553-61.

35. Better OS, Rubinstein I, Reis DN. Muscle crush compartment syndrome: fulminant local edema with threatening systemic effects. Kidney Int 2003;63:1155-7. Crossref

36. Blaisdell FW. The pathophysiology of skeletal muscle ischemia and the reperfusion syndrome: a review. Cardiovasc Surg 2002;10:620-30.

37. Sever MS, Erek E, Vanholder R, Kantarci G, Yavuz M, Turkmen A, et al. Serum potassium in the crush syndrome victims of the Marmara disaster. Clin Nephrol 2003;59:326-33. Crossref

38. Kenney K, Landau ME, Gonzalez RS, Hundertmark J, O’Brien K, Campbell WW. Serum creatine kinase after exercise: drawing the line between physiological response and exertional rhabdomyolysis. Muscle Nerve 2012;45:356-62. Crossref

39. Keltz E, Khan FY, Mann G. Rhabdomyolysis. The role of diagnostic and prognostic factors. Muscles Ligaments Tendons J 2014;3:303-12.

40. Weibrecht K, Dayno M, Darling C, Bird SB. Liver aminotransferases are elevated with rhabdomyolysis in the absence of significant liver injury. $\mathrm{J}$ Med Toxicol 2010;6:294-300. Crossref

\title{
DENEYSEL ÇALIŞMA - ÖZET
}

\section{Ezilme yaralanması oluşturulan sıçanlarda asetaminofen ve mannitolün etkileri: Deneysel çalışma}

\section{Dr. Mustafa Ferudun Çelikmen, ${ }^{1}$ Dr. Sezgin Sarıkaya, ${ }^{1}$ Dr. Doğaç Niyazi Özüçelik, ${ }^{2}$ Dr. Mehmet Şükrü Sever, ${ }^{3}$ Dr. Kurtuluş Açıksarı, ${ }^{4}$ Dr. Deniz Maktav Çelikmen, ${ }^{5}$ Dr. Mustafa Yazıcıoğlu, ${ }^{6}$ Dr. Ali Kandemir, ${ }^{1}$ Dr. Halil Doğan, ${ }^{6}$ Dr. Barış Murat Ayvacı, ${ }^{7}$ Dr. Derya Özaşır Abuşka, ${ }^{8}$ Dr. Sıla Sadıllıoğlu ${ }^{9}$}

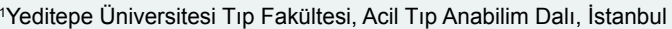 \\ ${ }^{2}$ İstanbul Üniversitesi Sağlık Bilimleri Fakültesi, İstanbul \\ ${ }^{3}$ İstanbul Üniversitesi Tıp Fakültesi, Nefroloji Bilim Dalı, İstanbul \\ ${ }^{4}$ İstanbul Medeniyet Üniversitesi Tıp Fakültesi, Acil Tıp Anabilim Dalı, İstanbu \\ ${ }^{5}$ Haydarpaşa Numune Eğitim ve Araştırma Hastanesi, İç Hastalıkları Kliniği, İstanbul \\ ${ }^{6}$ Bakırköy Dr. Sadi Konuk Eğitim ve Araştırma Hastanesi, Acil Tıp Kliniği, İstanbul \\ ${ }^{7}$ Okmeydanı Eğitim ve Araştırma Hastanesi, Acil Tıp Kliniği, İstanbul \\ ${ }^{8}$ Haseki Eğitim ve Arşatırma Hastanesi, Acil Tıp Kliniği, İstanbul \\ 'İstanbul Eğitim ve Araştırma Hastanesi, Acil Tıp Kliniği, İstanbul
}

AMAÇ: Bu çalışmada, mekanik ezilme yaralanması oluşturulan sıçanlarda, asetaminofen ve mannitolün böbrek fonksiyonu ve histopatolojisi üzerine etkileri araştıııldı.

GEREÇ VE YÖNTEM: Çalışmada 370-400 gram ağılığında 36 sıçan kullanıldı. Kontrol amaçıı birinci gruba bir işlem uygulanmadı. Diğer beş gruba ikişer saat süresince her iki bacak gastroknemius kası bölgesine mekanik ezilme işlemi uygulandı. Sonra dördüncü gruba asetaminofen $100 \mathrm{mg} / \mathrm{kg}$; beşinci gruba mannitol I gr/ kg; altıncı gruba asetaminofen $100 \mathrm{mg} / \mathrm{kg}$ ve mannitol I gr/ $\mathrm{kg}$ intraperitoneal verildi. Herhangi bir tedavi uygulanmayan ikinci grup iki saat sonra, üçüncü grup ve tedavi grupları ise 24 saat sonra sakrifiye edilerek kan ve doku örnekleri alındı.

BULGULAR: Sodyum, potasyum, alanin aminotranferaz, kreatinin, ortalama kreatinin klirensi değerleri açısından asetaminofen ve mannitol tedavi grupları arasında istatistiksel olarak anlamlı fark bulunmadı. Histopatolojik olarak hidropik dejenerasyon, tübüler nekroz, enflamasyon, tubulus lümeninde immünoperoksidaz ve miyoglobin varlığı, tubulus epitel hücre dejenerasyonu, tubulus lümeninde PAS boyanan materyel varlığı bulgularının mannitol uygulanan grupta azaldığı, asetaminofen uygulanan grupta mannitol uygulanan gruptan daha fazla azaldığı, asetaminofenle mannitol birlikte uygulandığında ise bulguların tek başına mannitol uygulamasından daha iyi, ancak tek başına asetaminofen uygulamasından daha iyi olmadığı görüldü. TARTIŞMA: Ezilme yaralanmalarında oluşan böbrek hasarında asetaminofen histopatolojik olarak mannitolden daha etkilidir. Asetamniofen mannitolle birlikte kullanıldığında ise karaciğere olan toksik etkisi daha az olmaktadır.

Anahtar sözcükler: Asetaminofen; böbrek hasarı; deprem; deneysel çalışma; ezilme yaralanması; mannitol. 